Memories of Tiananmen 


\section{China: From Revolution to Reform}

The China: From Revolution to Reform Series was launched by AUP to meet the rising influence of the People's Republic of China (PRC) as an economic, military, and political power in the world arena. Forty years after the Chinese Communist Party kicked off the reform, the PRC is now poised to surpass the United States as the world's greatest economy. A more confident and powerful PRC coupled with increasingly rich primary sources have drawn tremendous interest from scholars around the world. The primary focus of this series will be the PRC in the new era with somewhat dual attention to previous periods such as the Republic of China (1912-1949) and the late Qing (1644-1911), both of which are not only intertwined with and inseparable from the PRC but also crucial to our better understanding of the PRC. This series invites studies from a wide variety of disciplines and topics in politics, law, history, diplomacy, gender, and the like. Researches in earlier periods of 2 oth century China, Taiwan, or Hong Kong are also welcome.

\section{Series Editor}

Qiang Fang, University of Minnesota Duluth

\section{Editorial Board}

Xiaobing Li, University of Central Oklahoma

Chen Linghai, East University of Political Science and Law, Shanghai

Aminda Smith, Michigan State University

Harold Tanner, University of Northern Texas

Xiaoping Cong, University of Houston 


\title{
Memories of Tiananmen
}

\author{
Politics and Processes of Collective Remembering \\ in Hong Kong, 1989-2019
}

Francis L.F. Lee and

Joseph M. Chan 
Cover photo: Joseph M. Chan

Cover design: Coördesign, Leiden

Lay-out: Crius Group, Hulshout

$\begin{array}{ll}\text { ISBN } & 9789463728447 \\ \text { e-ISBN } & 9789048553044 \text { (pdf) } \\ \text { DOI } & 10.5117 / 9789463728447 \\ \text { NUR } & 692\end{array}$

(C) Francis L.F. Lee \& Joseph M. Chan / Amsterdam University Press B.V., Amsterdam 2021

All rights reserved. Without limiting the rights under copyright reserved above, no part of this book may be reproduced, stored in or introduced into a retrieval system, or transmitted, in any form or by any means (electronic, mechanical, photocopying, recording or otherwise) without the written permission of both the copyright owner and the author of the book.

Every effort has been made to obtain permission to use all copyrighted illustrations reproduced in this book. Nonetheless, whosoever believes to have rights to this material is advised to contact the publisher. 